DOI: https://doi.org/10.32839/2304-5809/2021-3-91-74

УДК 657

Дорош Н.І., Філоненко Н.М.

Київський національний університет імені Тараса Шевченка

\title{
КЛЮЧОВІ АСПЕКТИ СУТНОСТІ ЗАРОБІТНОЇ ПЛАТИ ТА ЇЇ ОПОДАТКУВАННЯ
}

Анотація. Розглянуто різні визначення науковців поняття «заробітна плата», фрункцї, системи оплати праці, досліджено закордонний досвід оплати праці, проаналізовано динаміку мінімальної заробітної плати в Україні та світі, середньомісячної заробітної плати та прожиткового мінімуму, а також максимальної бази оподаткування единого соціального внеску (ССB), досліджено актуальні зміни законодавства щодо оподаткування заробітної плати податку з доходів фрізичних осіб (ПДФО), військового збору (B3) та ССВ, нової форми звітності, а також виокремлення проблем щодо цих податків.

Ключові слова: заробітна плата, оплата праці, оподаткування, законодавство, звітність, мінімальна заробітна плата, середня заробітна плата, прожитковий мінімум, податки, податок з доходів фізичних осіб, військовий збір, единий соціальний внесок, закордонний досвід.

Dorosh Nina, Filonenko Nataliia Taras Shevchenko National University of Kyiv

\section{KEY ASPECTS OF THE ESSENCE OF SALARIES AND IT'S TAXATION}

Summary. Various definitions of scientists of the concept of "salary", functions, systems of remuneration are studied, foreign experience of remuneration is investigated, the dynamics of the minimum wage in Ukraine and the world, the average monthly wage and subsistence level, as well as the maximum base of SSC taxation is analyzed, current changes in the legislation on payroll taxation of PIT, military tax and SSC, a new form of reporting, as well as highlighting issues related to these taxes. However, the emergence of basic principles and the emergence of accounting for payments to employees dates back to the distant past and due to the development of economic life of society, in particular the division of labor and its implementation of varying degrees of complexity. In ancient Egypt in the third millennium BC. labor force was recorded and used, and at the Hellenistic stage, military units compiled payment statements, the results of which indicated the need to pay money to a representative of a military unit, provided he had a special receipt, which was verified with the payroll. In Babylon in the VIII century. B.C. kept records of personnel, working time, use of labor and maintenance costs, carried out planning, rationing and control of wage costs. In Persia (552-486 BC) for the first time recorded documentation of payments and payments to employees (filling out a document such as "requirement-dress", which received money or products). During the Roman Empire, the systematic recording of personnel costs was widely developed, separate personal accounts were formed, and clear terms of payment to employees. For the first time in the literature, the accounting of employee benefits is mentioned in the work of a prominent Italian monk, the "father of modern accounting" Luka Pacioli's "Treatise on Accounts and Records" (1494), which reveals the need for a separate account to reflect labor costs. 22 contains information on the accounting of salary costs for assistants and employees. In the XIX-XX centuries. Many scholars from various schools and schools, such as the Italian, German, French, Russian, and Ukrainian Soviet schools, worked on the problems of accounting for payroll. The above historical digression emphasizes that, in fact, at all stages of society's development, payroll calculations have been important in practice and have been the focus of many scholars and researchers in this field. Payments to employees continue to be important today, both nationally and internationally.

Keywords: wages, wages, taxation, legislation, reporting, minimum wage, average wage, subsistence level, taxes, personal income tax, military duty, single social contribution, foreign experience.

$\Pi$ остановка проблеми. Заробітна плата часто стає об'єктом наукових досліджень, оскільки для роботодавця вона є значним елементом витрат, для працівника - основною складовою частиною доходу. Заробітна плата $є$ одним 3 найважливіших інструментів управління виробництвом, оскільки вона безпосередньо впливає на мотивацію персоналу. Люди завжди будуть працювати, а отже, мають отримувати заробітну плату еквівалентну відпрацьованому часу (або виробленим одиницям продукціï) та профресіоналізму. На підприемствах ведеться бухгалтерський облік багатьох господарських операцій залежно від виду та специфіки господарської діяльності, зокрема і заробітної плати. Не зважаючи на це, підприемства мають справу з операціями щодо оподаткування заробітної плати в обов'язковому порядку, а тому оплата праці є одним 3 найважливіших об'єктів бухгалтерського обліку і фрінансової звітності.
Аналіз останніх досліджень і публікацій. Питання обліку та оподаткування операщій з оплати праці досліджували такі вчені: Н.Л. Вачевська, H.I. Дорош, Т.Г. Мельник, О.А. Садовніков, І.Л. Петрова та ін. В науково-економічній літературі існуе значна кількість визначень заробітної плати, а її автори постійно намагаються удосконалити трактування видів та фрункцій, які вона має виконувати. Проте існування різних підходів пов'язаних 3 тлумаченням заробітної плати та їі оплати призводить до неточностей у практичній діяльності підприемств у частині нарахування та відображення на рахунках бухгалтерського обліку операцій 3 оплати праці, а також у звітності. Крім того, численні зміни в оподаткуванні заробітної плати зумовлюють актуальність теми дослідження.

Виділення не вирішених раніше частин загальної проблеми. Сьогодні питання актуальності заробітної плати зростає щосекунди, 
темпи росту мінімальної та середньої заробітної плати сприяють підвищенню добробуту суспільства. Тому було проведено дослідження взаємозалежності ключових показників за 2015-2021 pp.

Постановка завдання. Метою дослідження є розкриття, систематизація та узагальнення теоретичних і методичних аспектів сутності заробітної плати та її оподаткування. Об'єктом дослідження є заробітна плата та господарські процеси, пов'язані з її нарахуванням та виплатою на підприемстві. Предметом виступають теоретико-методологічні та організаційно-практичні аспекти оподаткування заробітної плати на підприемстві.

Виклад основного матеріалу дослідження. Відповідно до ст. 1 Закону України «Про оплату праці», «заробітна плата - це винагорода обчислена у грошовому виразі, яку за трудовим договором власник або уповноважений ним орган виплачуе працівнику за виконану роботу» [4]. Для заробітної плати, як складової оплати праці і як правової категорії, характерними є певні ознаки, а саме: винагорода за виконання працівником трудових обов'язків, розмір якої визначається за наперед встановленими нормами і розцінками; заробітна плата має гарантований характер; їі розмір не може бути нижчим за мінімальний розмір оплати праці, визначений чинним законодавством [10].

Т.Г. Мельник трактуе визначення оплати праці як економічну й обліково-аналітичну категорію. Вона зауважуе на тому, що трудовий дохід працівника фрормуеться залежно від кількості та якості затраченої ним корисної праці та виплачуеться працедавцем у вигляді заробітної плати в грошовій або натуральній формі [7, с. 122].

Лепьохіна I.O. розкриває «заробітну плату - як об'єктивно необхідний для відтворення робочої сили та ефрективного фрункціонування виробництва обсяг вираженої у грошовій формі основної частини життевих засобів, що відповідає досягнутому рівню розвитку продуктивних сил і зростає пропорційно підвищенню ефективності праці робітників» [15, с. 76].

Інший підхід до змісту заробітної плати висловлюють Глухова С.В. і Зотова А.А. За їх трактуванням, «заробітна плата - це ціна, яку отримуе працівник, як винагороду в грошовому виразі, що стимулюе його до досягнення високих кінцевих результатів праці, з одного боку i елемент витрат виробництва 3 іншого». Також автори зазначають, що заробітна платня - це сукупність винагород у грошовій або натуральній формі, отриманих робітниками за фрактично виконану роботу, а також за періоди, які входять у робочий час [12, с. 699].

Слід зауважити, що поняття «заробітна плата» наповнилося новим змістом і охоплюе всі види заробітків, а також різних премій, доплат, надбавок і соціальних пільг, нарахованих у грошовій і натуральній формах незалежно від джерел фрінансування, включаючи грошові суми, нараховані працівникам відповідно до законодавства.

На практиці сутність заробітної плати проявляється у їі фрункціях. За визначенням, яке подає у своїх працях О. Валецька, «функції заробітної плати - це її призначення та роль як складової сорери практичної діяльності щодо узгодження i реалізації інтересів суб'єктів трудових відно- син» [11, с. 101]. В умовах функціонування ринкової економіки заробітна плата має виконувати багато фрункцій, які мають економічну, правову і соціальну природу.

Зокрема, Закон України «Про оплату праці» виділяе відтворювальну та стимулюючу функції [4]. Відтворювальна функція полягає у забезпеченні працівників та членів їхніх сімей необхідними життевими благами для відновлення робочої сили, для відтворення поколінь [9, с. 275]. Заробітна плата виступає основним джерелом коштів на відтворення робочої сили, тому Н. Болотіна пов'язує відтворювальну функцію з таким важливим соціальним стандартом, як прожитковий рівень, який характеризуе мінімально допустимі умови відновлення активного фрізичного стану людини [8, с. 86].

Стимулююча фрункція заробітної плати полягає у встановленні залежності їі розміру від кількості та якості праці конкретного працівника, його трудового внеску у результати роботи підприемства. Ця залежність повинна заохочувати пращівника до постійного покращання результатів праці [9, с. 275]. Деякі автори трактують цю функцію як інструмент впливу роботодавця на трудову поведінку найманих працівників через політику заробітної плати, а інші - як засіб дії внутрішніх мотивів працівників до покращення результатів праці [12, с. 103].

Важливе місце в регулюванні заробітної плати України займає тарифна система оплати пращі, яка виступає як сукупність взаємопов'язаних елементів: тарифрна сітка, тарифнна ставка, система посадових окладів, тарифнний коефіцієнт, тарифннкваліфікаційних довідник, кваліфікаційні довідники посад керівників, службовців і спеціалістів, доплати до тарифної системи і надбавки за відхилення від норм умов праці. Тарифною системою передбачені дві форми оплати праці - відрядна і погодинна, які включають ряд систем для різних організащійно-технічних умов виробництва.

В результаті дослідження встановлено, що більшість підприємств України використовують такі системи оплати пращі:

- пряма відрядна - оплата за кожну вироблену продукцію за незмінними розцінками;

- відрядно-преміальна - передбачає, крім заробітної плати, нарахованої за відрядними розцінками, виплату премій за досягнення високих результатів у роботі;

- відрядно-прогресивна - проводиться за відрядними розцінками в межах встановленого плану, а за випуск продукції понад план - за вищими розцінками;

- проста погодинна система оплати праці передбачає оплату праці залежно від відпрацьованого часу та рівня кваліфікації.

В умовах ринкової економіки системи оплати праці потребують реформування з огляду на працівників, продукцію, яку вони виготовляють, та її необхідності для задоволення потреб споживачів. Особливу увагу потрібно приділити відрядно-преміальній оплаті праці, оскільки вона передбачає, крім заробітної плати, нарахованої за відрядними розцінками, виплату премій за досягнення високих результатів у роботі.

Сьогодні, дуже важливим $е$ використання закордонного досвіду оплати праці при побудові 
чи коригуванні системи оплати праці на вітчиз-

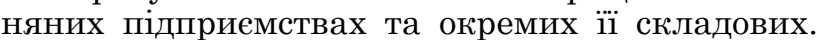
У країнах 3 довготривалою історією та розвиненою ринковою економікою існуе великий досвід застосування найрізноманітніших систем оплати праці. Зокрема у: Швеції - солідарна заробітна плата; Японії - оплата за стаж; Німеччині - стимулювання зростання продуктивності; США - оплата за кваліфрікащію; Великобританії - оплата за індивідуальними контрактами; Франції - індивідуалізація зарплати; Італії - виплатою колективних та індивідуальних надбавок до галузевої тарифної ставки і надбавками у зв'язку зі зростанням вартості життя [14].

У таких країнах за державою залишаються фрункції створення єдиної законодавчо-нормативної бази, яка сприяє ефрективному здійсненню всіх господарських, технічних й соціальних питань на підприемстві.

У багатьох країнах існують національні або відомчі нормативні акти, що регулюють основні нормативні акти щодо процедур встановлення, заміни та перегляду трудових норм. Однак у всіх випадках норми праці встановлюються безпосередньо конкретним підприемством. Некомерційні та приватні консультаційні центри, асоціації надають практичну допомогу підприемствам у цій роботі. Ці центри професійно займаються питаннями нормування праці та надають сучасні комп'ютерні технології підприемствам [13].

Законодавством про працю багатьох країн встановлено такі правила: правила оплати відпусток та святкових днів, шлюбів та інших виплат та компенсацій, простоїв, правил щодо порядку та строку виплати заробітної плати, методи захисту доходів працівників від надмірних відрахувань, індексація. Закордонні підприемства переважно використовуються погодинну оплату праці, головною передумовою цього є поліпшення якості продукщіi, а не кількості.

Механізм державного регулювання оплати праці в країнах ЄС базується на співвідношенні таких складових, як:

1) мінімальна заробітна плата (МЗП), граничні розміри її зростання у період інфляції, податкова політика (державне регулювання);

2) загальний порядок індексації доходів, фрорми і системи оплати праці тощо (колективнодоговірне регулювання на галузевому рівні);
3) розміри тарифнних ставок і окладів, доплат та надбавок (колективні договори);

4) середня заробітна плата (ринок робочої сили) [6].

В країнах Західної Свропи використовуються три моделі стимулювання праці: без преміальна (функщії кращої мотивації праці виконуе заробітна плата); преміальна, що додатково включає виплати пов'язані з розміром доходу чи прибутку підприемства; преміальна, що передбачає виплати, пов'язані 3 індивідуальними результатами праці. Преміальні моделі оплати праці фрункціонують: через участь у прибутках (річна диференційована винагорода з прибутку підприемства); через участь у доходах (з суми доходу кожному працівникові видається винагорода, пов'язана з виконанням завдання і не залежить від прибутку); через участь у капіталі (працівники одержують премії у вигляді акщій по їх номінальній вартості).

Особливістю систем стимулювання у європейських країнах $є$ широке розповсюдження заохочень за впровадження різноманітних нововведень. Зокрема більшість підприемств створюють преміальні фронди для спеціальної винагороди за створення, освоєння і випуск нової продукції, але їх розмір встановлюється залежно від приросту обсягу продажів нової продукції, її частки в обсязі виробництва. Вартим уваги є зарубіжний досвід формування та застосування системи матеріального заохочення персоналу, де визначальними елементами є: використання тарифної системи; застосування прогресивних форм оплати праці; вища оплата розумової пращі; істотна індивідуалізація заробітної плати. Поширеною є тарифна система як інструмент диференщіації оплати праці залежно від складності, умов і важливості роботи. У високорозвинених країнах переважно застосовуються єдині тарифні сітки для робітників, спеціалістів і службовців. Кожна галузь економіки, як правило, формуе власні тарифні сітки, які, у свою чергу, модифікуються на рівні фрірм. Досвід європейських країн із стійкою ринковою економікою до мінімальних державних гарантій у сорері оплати пращі включає: МЗП і прожитковий мінімум, порядок їх зміни залежно від зростання цін, порядок регулювання оплати праці залежно від місця проживання, шкідливості праці.

Оскільки різниця є дуже суттєвою, тому динаміку мінімальної зарплати України подано в рис. 1.

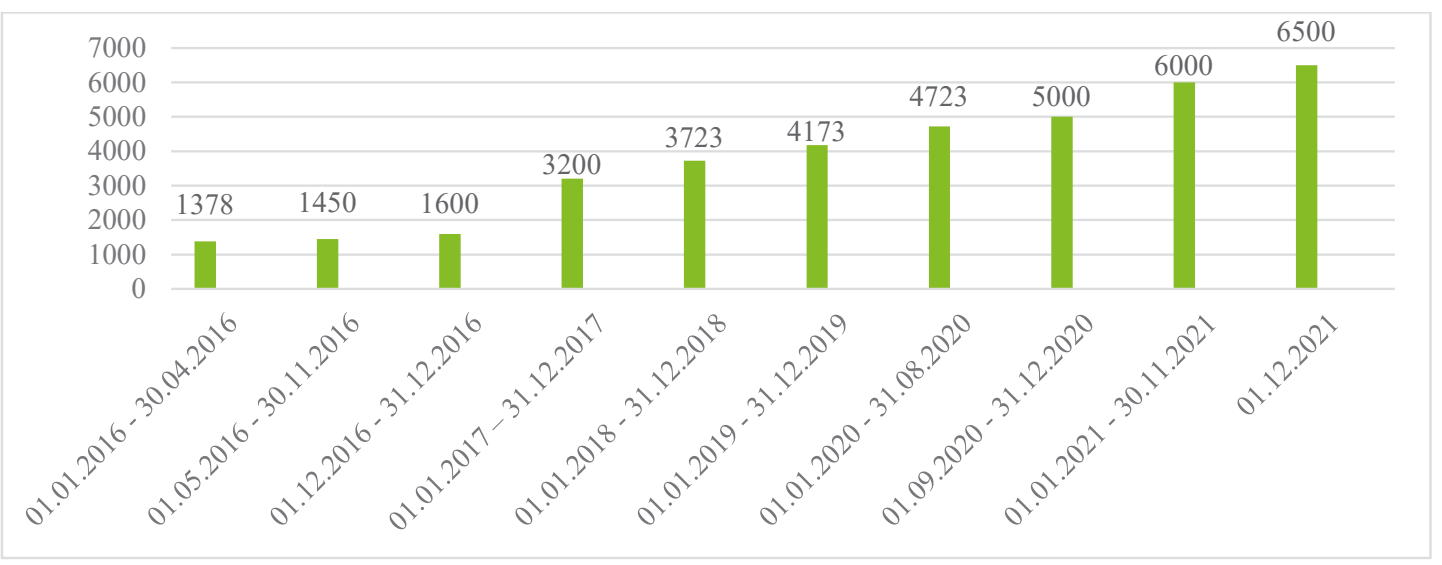

Рис. 1. Динаміка мінімальної зарплати в Україні за 2016-2021 рр.

Джерело: складено авторами за данили Законів України "Про Державний бюджет на відповідний рік" [2] 
Отже, з 1 січня 2021 року мінімальна заробітна плата зросла до 6000 грн, а в грудні цього ж року зросте ще на 500 грн.

Дослідимо також динаміку середньомісячної заробітної плати в Україні за 2016-2020рр.

Динаміка середньомісячної зарплати

Таблиця 1 в Україні за 2016-2021 рр.

\begin{tabular}{|c|c|}
\hline Рік & Розмір, грн. \\
\hline 2016 & 6475 \\
\hline 2017 & 8777 \\
\hline 2018 & 10573 \\
\hline 2019 & 12264 \\
\hline 2020 & 14179 \\
\hline
\end{tabular}

Джерело: складено авторами за даними Держкомстату [16]

Отже, за аналізований період прослідковуеться позитивна динаміка середньомісячної заробітної плати по Україні, на кінець 2020 року вона досягла 14179 грн.

Дослідимо залежність між МЗП та середньомісячною зарплатою, використавши дані на кінець 2016-2020 pр. в табл. 2.

Таблиця 2

Залежність МЗП та середньомісячної зарплати за 2015-2020 pp.

\begin{tabular}{|c|c|c|c|c|}
\hline Рік & 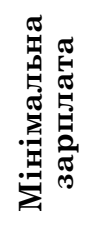 & 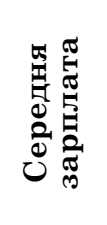 & 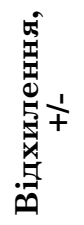 & 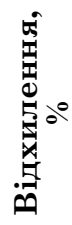 \\
\hline 2016 & 1600 & 6475 & 4875 & 305 \\
\hline 2017 & 3200 & 8777 & 5577 & 174 \\
\hline 2018 & 3723 & 10573 & 6850 & 184 \\
\hline 2019 & 4173 & 12264 & 8091 & 194 \\
\hline 2020 & 5000 & 14179 & 9179 & 184 \\
\hline
\end{tabular}

Джерело: складено авторами салостійно

Отже, за табл. 2 прослідковуеться суттеве перевищення середньої зарплати над мінімальною, найбільша різниця була у 2016 році та становила 305\%, далі відбувалось збільшення МЗП, тому цей відсоток значно скоротився, мінімальний ріст зафіксовано у 2017 році - 174\%. На кінець 2020 року, середня зарплата перевищувала мінімальну на 9179 грн або 184\%. Для візуалізації зобразимо на рис. 2 дану взаемозалежність.
Дослідимо залежність між МЗП та прожитковим мінімумом для працездатних осіб, використавши дані на кінець 2016-2020 рр. в табл. 3.

Таблиця 3

Залежність МЗП та прожиткового мінімуму за 2015-2020 pp.

\begin{tabular}{|c|c|c|c|c|}
\hline Рік & 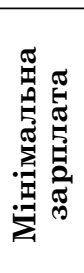 & 罗 & 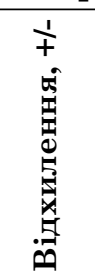 & 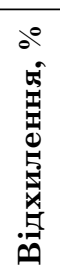 \\
\hline 2016 & 1600 & 1600 & 0 & 0 \\
\hline 2017 & 3200 & 1762 & -1438 & -45 \\
\hline 2018 & 3723 & 1921 & -1802 & -48 \\
\hline 2019 & 4173 & 2102 & -2071 & -50 \\
\hline 2020 & 5000 & 2189 & -2811 & -56 \\
\hline
\end{tabular}

Джерело: складено авторами самостійно

Отже, за табл. 3 прослідковуеться рівність МЗП та прожиткового мінімуму у 2016 році, проте 2017 року було збільшено МЗП вдвічі, а прожитковий мінімум зростав невеликими темпами. На кінець 2020 року, мінімальна заробітна плата перевищувала прожитковий мінімум на 2811 грн або 56\%. Для візуалізації зобразимо на рис. 3 дану взаємозалежність.

Для даного дослідження цікавим е порівняння МЗП України з іншими країнами аби зрозуміти на якому рівні ми наразі знаходимось, що подано у табл. 4.

Отже, у табл. 4 було проаналізовано дослідження сайту Picodi.com щодо рівня мінімальної заробітної плати різних країн світу, станом на 2021 рік. У результаті, було виявлено, що найбільше зросла МЗП України, а саме на 27\%. Крім того, українська МЗП перевищила мінімальні зарплати Узбекистану, Нігерії, Казахстану, Індії, Вірменії, Пакистану, Білорусії, Молдови, Азербайджану, Росії, Філіппін та В'єтнаму. За даним дослідженням було виявлено, що найменша МЗП в Узбекистані, на рівні 48 Свро, а найбільша в Люксембурзі, на рівні 1879 Євро. Для візуалізації зобразимо на рис. 4 дану взаємозалежність.

Оподаткування заробітної плати передбачае сплату податку на доходи фізичних осіб, військового збору та єдиного соціального внеску. При чому з суми зарплати утримуеться лише податок

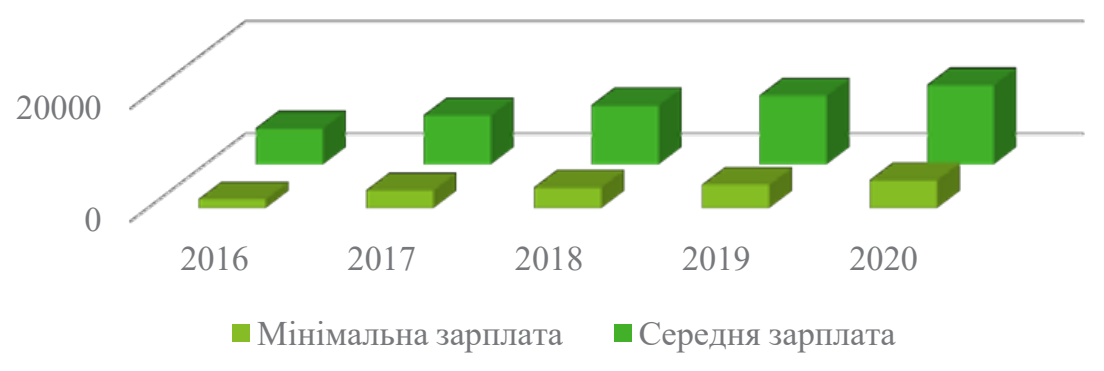

Рис. 2. Залежність МЗП та середньомісячної зарплати за 2015-2020 рр. 


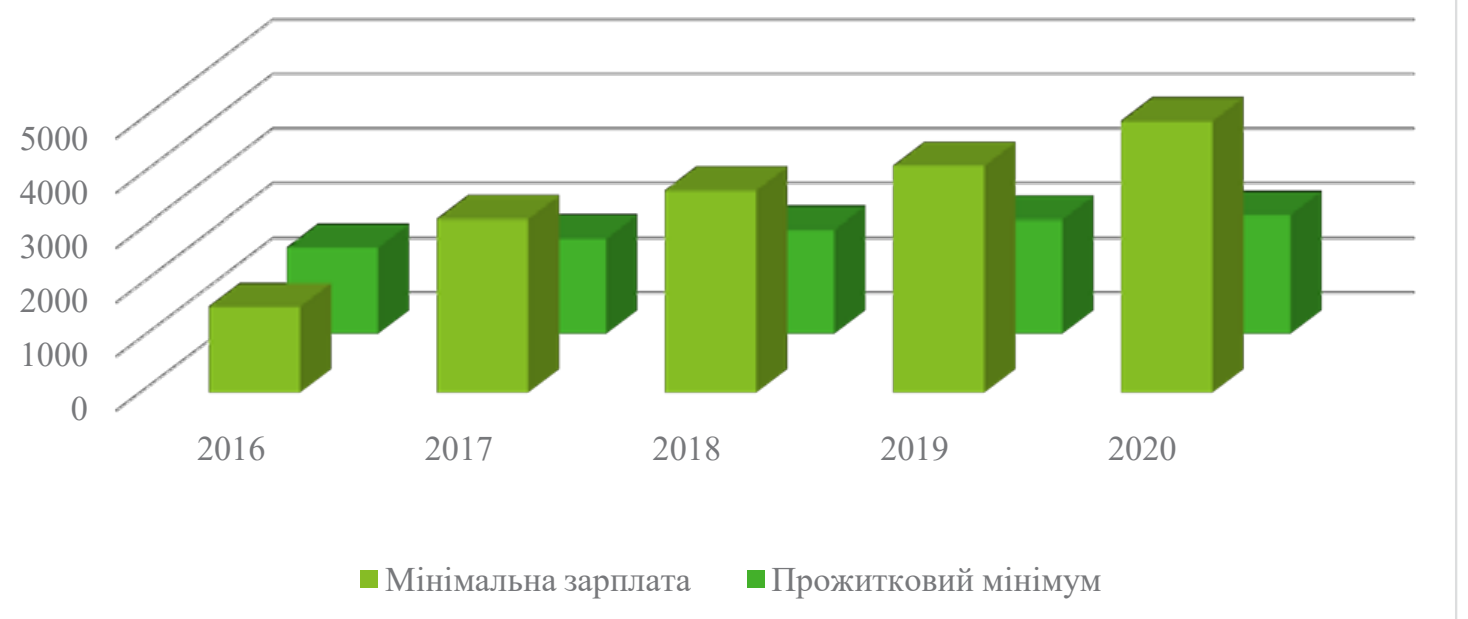

Рис. 3. Залежність МЗП та прожиткового мінімуму за 2015-2020 pp.

Джерело: складено авторами самостійно

на доходи фрізичних осіб та військовий збір, а єдиний соціальний внесок нараховуеться за рахунок витрат підприемства. Всі ці платежі сплачуються роботодавцем. Згідно з п. 167.1 Податкового кодексу України (ПКУ) [1], ПДФО утримується за ставкою $18 \%$.

В українському законодавстві є поняття податкової соціальної пільги (ПСП), що згідно пп. 169.1.1 ПКУ «є сумою, яка зменшуе базу оподаткування ПДФО при нарахуванні заробітної плати. ПСП встановлюеться у розмірі, що дорівнюе 50\% розміру прожиткового мінімуму для працездатної особи (у розрахунку на місяць), встановленому законом на 1 січня звітного податкового року» [1]. Станом на 1 січня 2021 року встановлено ПСП на рівні 1135 грн.

Відповідно, якщо працівник має право на ПСП, розрахунок слід здійснювати за формулою: ПДФО $=(3 П-\Pi С П) \times 18 \%$

Згідно з пп. 169.4.1 ПКУ, «працівник має право на ПСП тоді, коли зарплата працівнику за місяць не перевищуе суми, що дорівнюе розміру місячного прожиткового мінімуму, діючого для працездатної особи на 1 січня звітного року, помноженого на 1.4 та округленого до найближчих 10 грн» [1].

У 2021 р. така заробітна плата становить 3180 грн (= 2270×1,4 = 3178, тобто 3180 грн).

Разом 3 цим процес надання податкових соціальних пільг $є$ ускладненим. Порядок надання компенсацій 3 сум сплаченого доходу не пов'язаний з порядком сплати податку на нього. В умовах низької податкової грамотності населення і відсутності обов'язкового декларування доходів для багатьох категорій найманих працівників, більшість громадян не використовують дане своє законне право.

У цілому система соціальних пільг є неедективною. Головна причина - обмеження щодо розміру доходу, до якого може бути застосована податкова соціальна пільга, не відповідають реальному стану на ринку праці. За чинним законодавством мінімальна заробітна плата
Порівняння МЗП різних країн світу

Таблиця 4

з Україною, станом на 2021 р., Свро

\begin{tabular}{|c|c|c|c|c|}
\hline Країна & 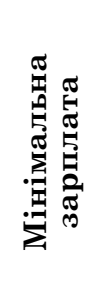 & 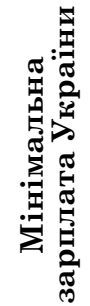 & 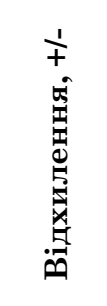 & 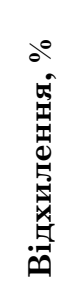 \\
\hline Узбекистан & 48 & 143 & 95 & 198 \\
\hline Нігерія & 59 & 143 & 84 & 142 \\
\hline Казахстан & 74 & 143 & 69 & 93 \\
\hline Індія & 80 & 143 & 63 & 79 \\
\hline Вірменія & 85 & 143 & 58 & 68 \\
\hline Пакистан & 91 & 143 & 52 & 57 \\
\hline Білорусь & 112 & 143 & 31 & 28 \\
\hline Молдова & 115 & 143 & 28 & 24 \\
\hline Азербайджан & 118 & 143 & 25 & 21 \\
\hline Росія & 123 & 143 & 20 & 16 \\
\hline Філіппіни & 128 & 143 & 15 & 12 \\
\hline Ветнам & 134 & 143 & 9 & 7 \\
\hline Албанія & 215 & 143 & -72 & -33 \\
\hline Туреччина & 301 & 143 & -158 & -52 \\
\hline Польща & 458 & 143 & -315 & -69 \\
\hline Чехія & 507 & 143 & -364 & -72 \\
\hline США & 938 & 143 & -795 & -85 \\
\hline Канада & 1217 & 143 & -1074 & -88 \\
\hline Ізраїль & 1221 & 143 & -1078 & -88 \\
\hline Франція & 1231 & 143 & -1088 & -88 \\
\hline Великобританія & 1417 & 143 & -1274 & -90 \\
\hline Австралія & 1745 & 143 & -1602 & -92 \\
\hline Люксимбург & 1879 & 143 & -1736 & -92 \\
\hline
\end{tabular}

Джерело: складено авторами за [20] 


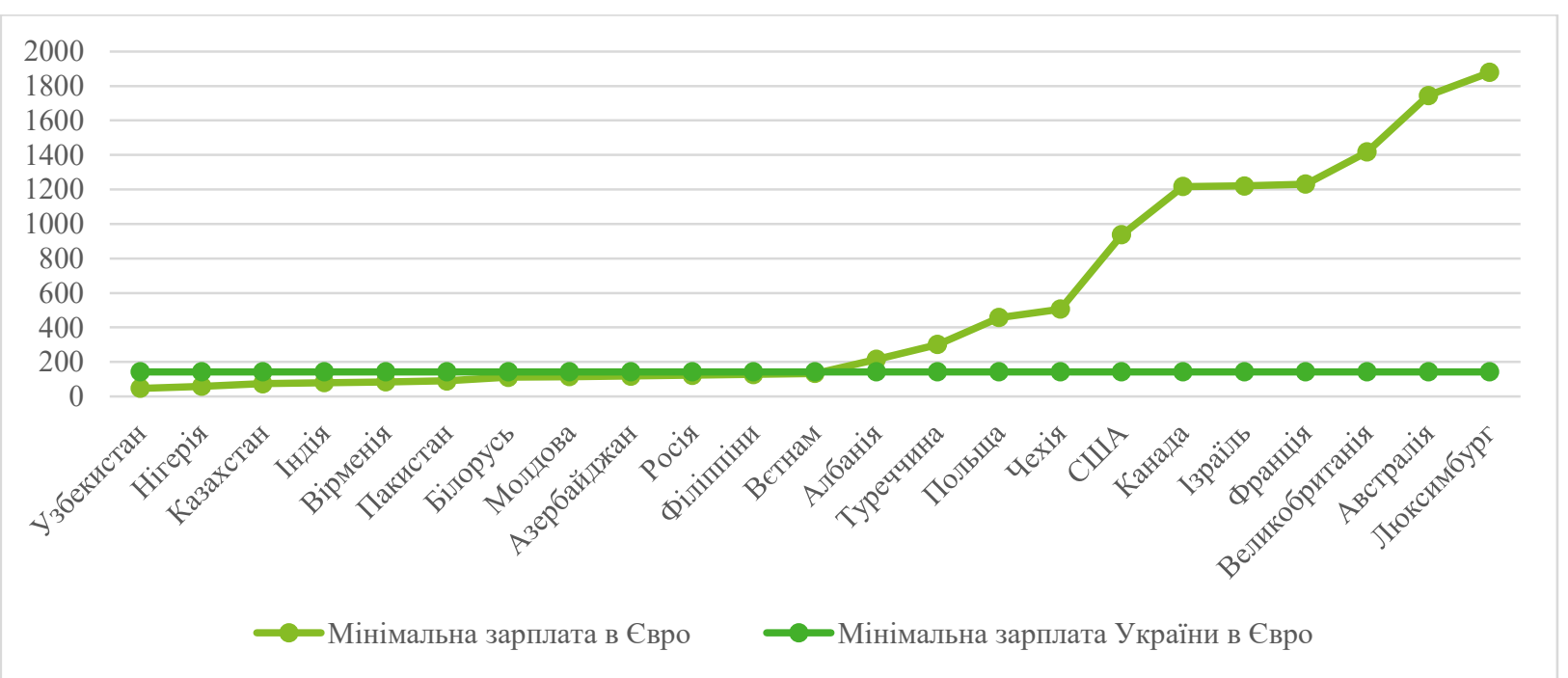

Рис. 4. Порівняння МЗП різних країн світу з Україною, станом на 2021 р.

прив'язана до фактичного прожиткового мінімуму, а право на отримання податкової соціальної пільги - до встановленого законом прожиткового мінімуму, Тобто, пільгою може скористатися лише працівники, які отримують заробітну плату нижче встановленого законом мінімуму, або низькооплачувані особи, зайняті на умовах неповного робочого дня.

Ставка військового збору $є$ незмінною, що складае $1,5 \%$ та використовуеться для розрахунку тимчасової втрати працездатності. В3 розраховується з повної суми нарахованої заробітної плати.

Окремі проблемні питання існують й щодо військового збору:

- військовий збір не включено до переліку загальнодержавних податків та зборів відповідно до ст. 9 ПКУ [1];

- надходження військового збору зараховуються до державного бюджету, а не до окремого цільового фонду.

По всім найманим працівникам роботодавці мають нараховувати та сплачувати ЄСВ (обов'язковий платіж до системи загальнообов'язкового державного соціального страхування). ЄСВ сплачуеться за ставкою $22 \%$ разом з ПДФО та ВЗ при виплаті зарплати.

Відповідно до п. 4 ч. I ст.1 Закону України «Про збір та облік единого внеску на загальнообов'язкове державне соціальне страхування» від 08.07.2010 р. № 2464-VI, «максимальна величина бази нарахування единого внеску це максимальна сума доходу застрахованої особи на місяць, що дорівнюе п'ятнадцяти розмірам мінімальної заробітної плати, встановленої законом, на яку нараховуеться единий внесок» [3].

Недоліком податкової системи України також є відсутність сімейного оподаткування. Працівники 3 низькими доходами не мають можливості зменшити свої податкові зобов'язання у зв'язку 3 наявністю утриманців (непрацездатні батьки, дружина, що перебувае у відпустці по догляду за дитиною, непрацездатні або тимчасово непрацездатні члени сім'ї, безробітні та особи, які опинилися у складних життевих обставинах).
Максимальні бази оподаткування ЄСВ відображено в табл. 5.

Таблиця 5

Динаміка максимальні бази оподаткування ССВ в Україні за 2016-2021 pp.

\begin{tabular}{|c|c|}
\hline Період діiі & Розмір, грн. \\
\hline $01.01 .2016-30.04 .2016$ & 34450 \\
\hline $01.05 .2016-30.11 .2016$ & 36250 \\
\hline $01.12 .2016-31.12 .2016$ & 40000 \\
\hline $01.01 .2017-30.04 .2017$ & 40000 \\
\hline $01.05 .2017-30.11 .2017$ & 42100 \\
\hline $01.12 .2017-31.12 .2017$ & 44050 \\
\hline $01.01 .2018-31.12 .2018$ & 55845 \\
\hline $01.01 .2019-31.12 .2019$ & 62595 \\
\hline $01.01 .2020-31.08 .2020$ & 70845 \\
\hline $01.09 .2020-31.12 .2020$ & 75000 \\
\hline $01.01 .2021-30.11 .2021$ & 90000 \\
\hline $01.12 .2021-31.12 .2021$ & 97500 \\
\hline
\end{tabular}

Джерело: згруповано авторами за даними Міністерства бонансів Украӥни [17]

Отже, у 31 січня 2021 року максимальна база оподаткування ССВ становить 90000 грн, а в грудні цього ж року зросте ще на 7500 грн.

Якщо зарплата працівника за місяць нижча за мінімальну, то донараховуеться ССВ на суму різниці з мінімальною базою. Проте мінімальна база ЄCB не може застосовуватись у випадках, коли працівник перебуває у трудових відносинах неповний місяць - прийнятий не в перший робочий день місяця й звільнений не в останній; працівник є зовнішнім сумісником; нарахування ЄСВ особам з інвалідністю, коли застосовуються знижені ставки $\operatorname{CBB}(8,41 \%, 5,5 \%, 5,3 \%)$; працівнику за місяць не було нараховано взагалі ніяких зарплатних або прирівняних до них виплат: ні зарплати, ні лікарняних, ні відпускних, ні декретних, тобто нічого [18]. Наприклад, працівник весь місяць був у відпустці за власний рахунок. При цьому по перехідних відпускних, лі- 
карняних, декретних слід здійснити помісячний розподіл.

Крім того, з 2021 року діє нова фрорма звітності, яка об'єднала в собі ЄСВ, ПДФО та ВЗ - Податковий розрахунок сум доходу [5].

В Податковому розрахунку сум доходу заповнюеться основна частина - за загальними даними по ЄСВ. Аналогічно таблиці 6 колишнього Звіту з ССВ за формою Д4 складається додаток Д1 - по ССВ (персоніфіковане нарахування ЄCB, різниця між мінімальною та фрактичною базою, код типу нарахувань). Схоже до застарілої формі 1ДФ заповнюеться додаток 4ДФ - по ПДФО та ВЗ [5; 19]. Подаеться Податковий розрахунок протягом 40 к. днів після кінця кварталу, а податки сплачуються одночасно з виплатою зарплати.

Висновки 3 даного дослідження. Проаналізувавши рівень мінімальної та середньої зарплати в Україні, можемо сказати, що вона є досить низькою, особливо у порівнянні з високорозвиненими країнами. Така ситуація не збільшуе зацікавленість працівників у досягненні високих результатів. У свою чергу, роботодавці не мають стимулу збільшувати продуктивність праці, витрачаючи гроші на інноваційне обладнання та технології, використовуючи дешеву робочу силу. Система компенсащій має колективно задовольняти інтереси всіх сторін, що беруть участь у компенсаційних відносинах, перш ніж вона набуде чинності. Однак у будь-якому випадку в цих відносинах завжди будуть сторони або окремі суб'екти, які не задоволені певними аспектами системи оплати праці або їі рівня. Тому при встановленні або регулюванні системи оплати праці вітчизняних підприемств та їх різноманітних складових необхідно застосовувати передовий досвід розвинених країн. Зокрема, досвід європейських країн із стійкою ринковою економікою до мінімальних державних гарантій у сфрері оплати праці включає: МЗП і прожитковий мі- німум, порядок їх зміни залежно від інфрлящї, порядок регулювання оплати праці залежно від місця проживання, шкідливості праці.

Оподаткування заробітної плати передбачає сплату податку на доходи фізичних осіб, військового збору та единого соціального внеску. При чому з суми зарплати утримуеться лише ПДФО та B3, а ЄCB нараховується за рахунок витрат підприемства. Всі ці платежі сплачуються роботодавцем. 32021 року діє нова форма звітності, яка об'єднала в собі ССВ, ПДФО та ВЗ - Податковий розрахунок сум доходу.

Так як, у законодавстві прописані особливості надання ПСП щодо ПДФО, акцентуємо увагу на неефективності такої пільги. Головна причина обмеження щодо розміру доходу, до якого може бути застосована податкова соціальна пільга, не відповідають реальному стану на ринку пращі. За чинним законодавством мінімальна заробітна плата прив'язана до фрактичного прожиткового мінімуму, а право на отримання податкової соціальної пільги -до встановленого законом прожиткового мінімуму, Тобто, пільгою може скористатися лише працівники, які отримують заробітну плату нижче встановленого законом мінімуму, або низькооплачувані особи, зайняті на умовах неповного робочого дня.

Основними проблемами щодо військового збору $є$ не включення до переліку загальнодержавних податків та зборів (ст. 9 ПКУ) та надходження В3 зараховуються до державного бюджету, а не до окремого цільового фронду.

Недоліком податкової системи України також є відсутність сімейного оподаткування. Працівники 3 низькими доходами не мають можливості зменшити свої податкові зобов'язання у зв'язку 3 наявністю утриманців (непрацездатні батьки, дружина, що перебуває у відпустці по догляду за дитиною, непрацездатні або тимчасово непрацездатні члени сім'і, безробітні та особи, які опинилися у складних життевих обставинах).

\section{Список літератури:}

1. Податковий кодекс України від 2 груд. 2010 р. № 2755-I. URL: https://zakon.rada.gov.ua/laws/show/2755-17 (дата звернення: 26.02.2021).

2. Про Державний бюджет на відповідний рік : Закон України URL: https://zakon.rada.gov.ua/laws/show/1082-20 (дата звернення: 23.02.2021).

3. Про збір та облік єдиного внеску на загальнообов'язкове державне соціальне страхування : Закон України від 8 лип. 2010 р. № 2464-V. URL: https://zakon.rada.gov.ua/laws/show/2464-17 (дата звернення: 25.02.2021).

4. Про оплату праці : Закон України від 24 бер.1995 р. №108/95-вр. URL: http://zakon5.rada.gov.ua/laws/ show/108/95-вр (дата звернення: 26.02.2021).

5. Податковий розрахунок сум доходу : затв. наказом М-ва фінансів України від 15 груд. 2020 р. № 773. URL: https://zakon.rada.gov.ua/laws/show/z1304-20

6. Дослідження проблем оплати праці: порівняльний аналіз (Україна та країни ЄС) : монографрія / А.М. Колот, Г.Т. Куліков, О.М. Поплавська. Київ : КНЕУ, 2018. 274 с.

7. Мельник Т.Г. Облік, аналіз та аудит праці і йї оплати : дис. ... канд. екон. наук : 08.06.04 / Київський національний ун-т ім. Тараса Шевченка, 2005. 284 с.

8. Болотіна Н.Б. Трудове право України : підручник. Київ : Вікар, 2004. 645 с.

9. Грішнова О.А. Економіка праці та соціально-трудові відносини : підручник. Київ : Знання, 2009.291 с.

10. Трудове право України : Навчальний посібник. Вид. 3-те, переробл. і доп. / за ред. П.Д. Пилипенка. Київ : Істина, 2010. 208 с

11. Валецька О.В. Забезпечення фрункцій заробітної плати: економіко-правовий аспект. Університетські наукові записки. 2006. № 3-4 (19-20). С. 282 .

12. Глухова С.В., Зотова А.А. Підходи до сутності заробітної плати. Молодий вчений. 2016. № 12.1(40). С. 698-700.

13. Дзюба С.Г., Гайдай І.Ю. Напрямки використання міжнародного досвіду організації нормування і оплати праці в контексті глобалізації економіки. Научные труды ДонНТУ. Серия экономическая. 2018. Выпуск 87. С. $159-165$.

14. Колот А.М. Зарубіжний досвід матеріального стимулювання персоналу. Украӥна: аспекти праці. 2017. Вип. $1.28 \mathrm{c}$.

15. Лепьохіна I.O. Теоретичні аспекти формування заробітної плати та ї функції. Вісник ЖДТУ. 2011. Вип. 2(56). С. 76-78. 
16. Державна служба статистики України : веб-сайт. URL: http://www.ukrstat.gov.uа (дата звернення: 20.02.2021).

17. Єдиний соціальний внесок в Україні з 2011 по 2021 рр. Міністерство фбінансів України : веб-сайт. URL: https://index.minfin.com.ua/ua/labour/social/ (дата звернення: 23.02.2021).

18. Мінімальна база нарахування ЄСB: визначаємо суму різниці та відображаємо у Звіті з ССВ. Інтерактивна бухгалтерія : веб-сайт. URL: https://interbuh.com.ua/ua/documents/ib/8720/120987 (дата звернення: 26.02.2021)

19. Утримання із заробітної плати 2021 р. Головбух : веб-сайт. URL: https://www.golovbukh.ua/article/7612podatki-z-zarplati (дата звернення: 26.02.2021).

20. Płaca minimalna na świecie: jak pandemia wpłynęła na najmniej zarabiających. Picodi. 2021. URL: https://www.picodi.com/pl/mozna-taniej/placa-minimalna-2021 (дата звернення: 28.02.2021).

\section{References:}

1. Tax Code of Ukraine from 2 Chr. 2010 № 2755-I. URL: https://zakon.rada.gov.ua/Laws/show/2755-17 (accessed 26 February 2021).

2. About the state budget for the relevant year: URL Law: https://zakon.rada.gov.ua/Laws/show/1082-20 (accessed 23 February 2021).

3. On collection and accounting of a single contribution to compulsory state social insurance: the Law of Ukraine of 8 Jul. 2010 № 2464-V. URL: https://zakon.rada.gov.ua/Laws/show/2464-17 (accessed 25 February 2021).

4. About wages: Law of Ukraine of 24 Mar. 1995 No. 108/95-BP. URL: http://zakon5.rada.gov.ua/Laws/show/108/95-Br (accessed 26 February 2021).

5. Tax calculation of the amount of income: Zatv. By order of Ukraine's finance of Ukraine from 15 breast. 2020 № 773. URL: https://zakon.rada.gov.ua/Laws/show/z1304-20

6. Research of remuneration problems: Comparative analysis (Ukraine and EU countries): monograph (2018) / A.M. Kolot, G.T. Kulikov, O.M. Poplavskaya. Kyiv: KNEU, 274 p.

7. Melnik T.G. (2005) Accounting, analysis and audit of labor and its payment: Dis. ... Cand. Econom. Sciences: 08.06.04 / Kiev National un-t them. Taras Shevchenko, 284 p.

8. Bolotin N.B. (2004) Labor Law of Ukraine: Tutorial. Kyiv: Vikar, 645 p.

9. Griznova O.A. (2009) Labor economy and socio-labor relations: tutorial. Kyiv: Knowledge, 291 p.

10. Labor Law of Ukraine: Tutorial. Kind. 3rd, recycling. and dop. / Ed. Pd. Pilipenko. Kyiv: Truth, 2010.208 p.

11. Valetskaya O.V. (2006) Providing wage functions: Economic and legal aspect. University Scientific Notes, no. 3-4 (19-20), p. 282.

12. Glukhova S.V., Zotova A.A. (2016) Approaches to the entity of wages. Young scientist, no. 12.1(40), pp. 698-700.

13. Dzyuba S.G., Gaidai I.Yu. (2018) Directions of use of international experience of organization of rationing and remuneration in the context of globalization of the economy. Scientific works of DonNTU. Series are economic, vol. 87, pp. 159-165.

14. Kolota A.M. (2017) Foreign experience of material stimulation of personnel. Ukraine: aspects of labor, vol. 1, 28 p.

15. Lepohin I.O. (2011) Theoretical aspects of wage formation and its functions. Bulletin of Zhdthou, vol. 2(56), pp. 76-78.

16. State Statistics Service of Ukraine. URL: http://www.ukrstat.gov.ua (accessed 20 February 2021).

17. The only social contribution to Ukraine from 2011 to 2021 Ministry of Finance of Ukraine: website. URL: https://index.minfin.com.ua/ua/labour/social/ (accessed 23 February 2021).

18. The minimum database of the ECV: we determine the amount of difference and reflect in the report from the ECU. Interactive Accounting: website. URL: https://interbuh.com.ua/ua/documents/IB/8720/120987 (accessed 26 February 2021).

19. Maintaining from the wage of 2021 Headbow: website. URL: https://www.golovbukh.ua/article/7612-podatki-zzarplati (accessed 26 February 2021).

20. Płaca minimalna na świecie: jak pandemia wpłynęła na najmniej zarabiających. Picodi. 2021. URL: https://www.picodi.com/pl/mozna-taniej/placa-minimalna-2021 (accessed 28 February 2021). 